\title{
PENGARUH SUBTITUSI SEBAGIAN RANSUM DENGAN TEPUNG TOMAT (Solanum Lycopersicum L) TERHADAP BERAT TELUR, BERAT KUNING TELUR DAN MASSA TELUR AYAM RAS
}

\author{
Mubaraq Nasikin*, F.J. Nangoy**, C.L.K. Sarayar** dan M.H.M. Kawatu** \\ Fakultas Peternakan Universitas Sam Ratulangi, Manado \\ Email :mubaraqn@gmail.com
}

\begin{abstract}
ABSTRAK
Penelitian ini bertujuan untuk mengetahui subtitusi sebagian ransum dengan tepung tomat (Solanum Lycopersicum L) terhadap berat telur, berat kuning telur, dan massa telur ayam ras. Penelitian ini dilaksanakan di Perusahaan Peternakan Dharma Gunawan, yang terletak di Kayuwatu Kecamatan Mapanget Kota Manado, sejak tanggal 14 September sampai 16 November 2014. Pengukuran kualitas telur dilakukan di Laboratorium Teknologi Hasil Ternak, Fakultas Peternakan Universitas Sam Ratulangi Manado, dengan menggunakan 100 ekor ayam ras petelur. Materi dibagi dalam 25 unit kandang, masing-masing ditempati 4 ekor. Rancangan Penelitian yang digunakan yaitu Rancangan Acak Lengkap (RAL) dengan 5 perlakuan dengan 5 ulangan. Adapun level perlakuan yaitu R0=Ransum dasar tanpa menggunakan tepung tomat, R1= Ransum dasar $98 \%+2 \%$ tepung tomat, R2 = Ransum dasar $96 \%+4 \%$ tepung tomat, R3 = Ransum dasar $94 \%+6 \%$ tepung tomat, R4 = Ransum dasar $92 \%+8 \%$ tepung tomat.

Variabel yang diamati meliputi Berat telur, berat kuning telur, dan massa telur. Hasil analisis keragaman menunjukkan bahwa perlakuan tidak memberikan pengaruh yang nyata $(\mathrm{P}>0,05)$ terhadap berat telur, berat kuning telur dan massa telur. Sehingga dapat disimpulkan bahwa subtitusi $2 \%-8 \%$ tepung tomat tidak memberikan pengaruh terhadap kualitas berat telur, berat kuning telur dan massa telur.
\end{abstract}

Kata Kunci : Tomat (Solanum Lycopersicum $L$ ), Telur, Ayam ras petelur

\footnotetext{
*Alumni Fakultas Peternakan Unsrat

** Jurusan Produksi Ternak
}

\begin{abstract}
EFFECT OF SOME SUBSTITUTION RATION TOMATO WITH WHEAT (SolanumLycopersicum L) ON HEAVY EGGS, WEIGHT YELLOW CHICKEN EGGS AND EGG MASS RAS. This study aims to determine the most ration with flour substitute tomato (Solanum Lycopersicum L) on egg weight, yolk weight and mass of eggs. This research was conducted at the Company's Ranch Dharma Gunawan, located in the District Kayuwatu Mapanget Manado City, from September 14 to 16 November 2014. Measuring the quality of the eggs is done in Laboratory Animal Product Technology, Faculty of Animal Sciences University of Sam Ratulangi, using 100 chickens race laying. The material is divided into 25 units of cages, each occupied 4 tails. Research design used is completely randomized design (CRD) with 5 treatments with 5 replications. As for the level of treatment that is $\mathrm{R} 0=$ basic ration without using flour tomatoes, $\mathrm{R} 1=$ basic ration $98 \%+$ $2 \%$ tomato powder, basic ration $\mathrm{R} 2=96 \%+$ $4 \%$ tomato powder, $\mathrm{R} 3$ = basic ration $94 \%+$ $6 \%$ tomato powder, $\mathrm{R} 4=$ basic ration $92 \%+$ $8 \%$ flour tomatoes.

Variables observed included egg weight, yolk weight, and egg mass. Results of analysis of variance showed that the treatment was not significant effect ( $\mathrm{P}>0.05)$ on egg weight, yolk weight and mass of eggs. It can be concluded that the substitution of $2 \%-8 \%$ tomato powder no effect on the quality of egg weight, yolk weight and mass of eggs.
\end{abstract}

Keywords: Tomato (Solanum Lycopersicum $L$ ), Egg, Chicken laying 


\section{PENDAHULUAN}

Usaha peternakan ayam ras petelur memiliki potensi yang cukup besar untuk dikembangkan sebagai salah satu sumber protein hewani yang dapat memenuhi kebutuhan gizi masyarakat. Usaha pengembangan ternak ayam ras petelur di Indonesia memiliki prospek yang cukup baik, terutama bila ditinjau dari aspek masyarakat akan kebutuhan gizi. Sesuai standar nasional, konsumsi per hari per kapita ditetapkan 55 g yang terdiri dari $80 \%$ protein nabati dan $20 \%$ hewani (Sudarmono, 2003).

Tomat (solanum lycopersicum $l$ ) selain digunakan sebagai minuman jus dapat juga dimanfaatkan sebagai bahan makanan ayam petelur. Tanti dan Sunarmani (2008) menyatakan tomat merupakan salah satu produk holtikultura yang menyehatkan dan mempunyai prospek pasar yang cukup menjanjikan. Buah tomat juga mengandung likopen. Likopen juga banyak terdapat pada buahbuahan yang berwarna merah, termasuk tomat, paprika, jambu biji, semangka, anggur, dan pepaya.

Likopen adalah salah satu pigmen kuning tua sampai merah tua yang termasuk kelompok karotenoid yang bertanggung jawab terhadap warna merah pada tomat. Dibalik warnanya yang merah, buah tomat banyak mengandung zat gizi, salah satunya adalah vitamin $\mathrm{C}$. Kandungan vitamin C dalam 100 gr buah tomat masak yaitu $40 \mathrm{mg}$. Tomat mengandung lemak dan kalori dalam jumlah rendah, bebaskolesterol, dan merupakan sumber serat danproteinyang baik. Selain itu, tomat kaya akan vitamin A danC, beta-karoten, kalium dan antioksidan. Satubuah tomat ukuran sedang mengandung hampirsetengah batas jumlah kebutuhan harian (required dailyallowance/RDA) vitamin $\mathrm{C}$ untuk orang dewasa (Franceschi et. al., 1994).Antioksidan didalam tubuh ternak dapat meningkatkan daya tahan tubuh ternak. Laszalo et al (2005) dalam Sudjarwo (2011) melaporkan bahwa senyawa likopen sebagai hasil pengolahan tomat dan turunannya bisa dijadikan dalam bahan pakan ternak unggas.

Tomat (solanum lycopersicum $l$ ) merupakan salah satu alternatif bahan penyusun ransum yang belum lazim digunakan dan merupakan sumber gizi yang cukup baik. Bahan pakan nabati yang mempunyai keunggulan kandungan nutrien setelah kombinasi dengan bahan pakan hewani dapat menghasilkan ransum dengan kandungan nutrien seimbang.

Telur merupakan salah satu produk unggas yang memberikan kontribusi besar dalam pemenuhan kebutuhan protein. 
Kualitas telur sendiri dapat dilihat dari kualitas internal dan external telur. Kualitas internal dapat dilihat dari haugh unit, warna kuning telur, indeks kuning telur, indeks putih telur sedangkan kualitas exsternal dapat dilihat dari tekstur, warna, bentuk, keutuhan dan kebersihan telur. Dimasyarakat telur dapat disiapkan dalam berbagai bentuk olahan, harganya relatif murah, sangat mudah diperoleh dan selalu tersedia setiap saat. Hal ini menyebabkan telur banyak dipilih oleh masyarakat. Daya guna telur membuat jangkauan pemasarannya sangat luas, sehingga kualitas telur menjadi perhatian masyarakat. Kismono (1999) menyatakan bahwa kualitas adalah kumpulan ciri-ciri suatu produk yang ada hubungannya dengan daya guna dan berpengaruh terhadap penerimaan konsumen. Kualitas telur adalah sekumpulan sifat-sifat yang dimiliki oleh telur dan mempunyai pengaruh terhadap penilaian atau pemilihan konsumen (Abbas, 1989).Kualitas telur ayam ras dapat dipengaruhi oleh ransum yang digunakan pada ternak ayam. Dewasa ini upaya penggunaan ragam makanan ternak lebih diarahkan pada tersedianya sumber pakan berkualitas. Untuk memperoleh pakan yang berkualitas, maka kandungan zat-zat makanan yang terdapat didalam pakan harus mempunyai nilai nutritif yang cukup serta sesuai dengan kebutuhan ternak tersebut. Berdasarkan pemikiran diatas, maka telah dilakukan suatu penelitian mengenai Subtitusi sebagian ransum dengan Tepung Tomat (solanum lycopersicum l) Terhadap Berat Telur, Berat Kuning Telur dan Massa Telur mampu memperbaiki kualitas telur ayam ras petelur.

\section{MATERI DAN METODE PENELITIAN}

Penelitian ini dilaksanakan melalui suatu percobaan selama 10 minggu bertempat di Perusahaan Peternakan Dharma Gunawan, yang terletak di Kayuwatu Kecamatan Mapanget Kota Manado, sejak tanggal 14 September sampai 16 November 2014 yang terdiri dari 7 hari masa pendahuluan dan 56 hari masa pengambilan data. Pengukuran kualitas telur dilakukan di Laboratorium Teknologi Hasil Ternak, Fakultas Peternakan Universitas Sam Ratulangi. Ransum perlakuan diberikan sebanyak 125 g/ekor/hari dan diberikan sebanyak 2 kali yaitu pada pagi hari pukul 06.00 WITA sebanyak $50 \%$ dan sisanya pada siang hari pukul 14.00 WITA. Air minum diberikan secara ad libitum. Pengambilan telur dilakukan pada pagi hari pukul 10.00 WITA dan siang hari pukul 16.00 WITA sedangkan pengambilan telur untuk analisis dilakukan setiap hari selasa setiap 
minggu selama periode penelitian. Setiap perlakuan diambil 1 butir telur sebagai sample untuk dianalisis di Laboratorium Teknologi Hasil Ternak, Fakultas Peternakan Universitas Sam Ratulangi.

Ternak yang digunakan dalam penelitian ini adalah ayam ras petelur fase layer yaitu umur 36 minggu dari jenis MB 402 sebanyak 100 ekor. Kandang yang digunakan dalam peneletian ini adalah kandang battery yang terdiri dari 25 unit dan setiap unit kandang ditempati 4 ekor ayam.Sebelum kandang digunakan, terlebih dahulu kandang disucihamakan yaitu dibersihkan dari kotoran dengan menggunakan detergen, air, dan kemudian didesinfektan menggunakan air kapur. Alat lain yang digunakan yaitu timbangan digital.

Metode penelitian yang digunakan adalah Rancangan Acak Lengkap (RAL) dengan 5 perlakuan dan 5 ulangan. Adapun level perlakuan yaitu R0 = Ransum dasar tanpa menggunakan tepung tomat, $\mathrm{R} 1=$ Ransum dasar $98 \%+2 \%$ tepung tomat, $\mathrm{R} 2=$ Ransum dasar $96 \%+$ $4 \%$ tepung tomat, $\mathrm{R} 3=$ Ransum dasar $94 \%+6 \%$ tepung tomat, $\mathrm{R} 4=$ Ransum dasar $92 \%+8 \%$ tepung tomat.

Komposisi zat-zat makanan, komposisi ransum percobaan, komposisi ransum control, komposisi zat-zat makanan ransum percobaan dapat dilihat pada Tabel 1, 2, 3 dan 4.

Tabel 1. Komposisi Zat-zat dan Bahan Makanan Ransum Percobaan

\begin{tabular}{lcccccc}
\hline Bahan makanan & Protein & Lemak & Serat kasar & $\mathrm{Ca}$ & $\mathrm{P}$ & $\begin{array}{c}\text { ME } \\
\text { (Kkal) }\end{array}$ \\
\hline TepungTomat & $16,73^{*}$ & $1,53^{*}$ & $30,94^{*}$ & $0.98^{*}$ & $1.20^{*}$ & $2416^{* *}$ \\
Jagung & 8,8 & 3,9 & 2 & 0,02 & 0,28 & 3350 \\
Dedak & 12,0 & 13 & 12 & 0,12 & 0,5 & 1630 \\
Tepung ikan & 60,0 & 9 & 1 & 5,5 & 0,3 & 2830 \\
CaCO $_{3}$ & - & - & - & 29,40 & 12,50 & 1000 \\
Konsentrat Cal 9.36 & 12,6 & 10 & 7 & 3 & 2 & 2600 \\
\hline
\end{tabular}

*) Berdasarkan Hasil Analisa Balai Riset dan Standarisasi Industri Manado 2014

**) Hasil Analisa Laboratorium Ilmu dan Teknologi Pakan Fakultas Peternakan IPB 2014

Tabel 2. Komposisi Ransum Kontrol

\begin{tabular}{cccccc}
\hline \multirow{2}{*}{ BahanMakanan } & Jagung & Dedak & $\begin{array}{c}\text { Tepung } \\
\text { Ikan }\end{array}$ & $\mathrm{CaCO}_{3}$ & Konsentrat \\
\cline { 2 - 6 } & \multicolumn{5}{c}{$(\%)$} \\
Jumlah (100) & 51 & 14 & 7 & 6 & 22 \\
\hline
\end{tabular}


Tabel 3. Komposisi Ransum Percobaan

\begin{tabular}{lccccc}
\hline \multirow{2}{*}{ BahanMakanan } & $\mathrm{R}_{0}$ & $\mathrm{R}_{1}$ & $\mathrm{R}_{2}$ & $\mathrm{R}_{3}$ & $\mathrm{R}_{4}$ \\
\cline { 2 - 6 } & 100 & 98 & 96 & 94 & 92 \\
Ransum Basal & 0 & 2 & 4 & 6 & 8 \\
Tomat & 100 & 100 & 100 & 100 & 100 \\
\hline Total & & & &
\end{tabular}

Tabel 4. Komposisi Zat-zat Makanan Ransum Percobaan

\begin{tabular}{lccccc}
\hline \multirow{2}{*}{ KomposisiZat-zatMakanan } & \multicolumn{5}{c}{ Persentase (\%) } \\
\cline { 2 - 6 } & $\mathrm{R}_{0}$ & $\mathrm{R}_{1}$ & $\mathrm{R}_{2}$ & $\mathrm{R}_{3}$ & $\mathrm{R}_{4}$ \\
\hline Protein & 17,49 & 17,47 & 17,45 & 17,44 & 17,42 \\
Lemak & 6,63 & 6,61 & 6,59 & 6,57 & 6,56 \\
Seratkasar & 4,31 & 5,41 & 6,5 & 7,24 & 8,69 \\
Ca & 2,76 & 2,75 & 2,69 & 2,66 & 2,56 \\
P & 1,42 & 1,16 & 1,42 & 1,41 & 1,40 \\
ME (Kkal) & 2766 & 2759 & 2752 & 2745 & 2738 \\
\hline
\end{tabular}

Keterangan :Hasil perhitungan berdasarkan Patrick and Schaaible (1982).

\section{HASIL DAN PEMBAHASAN}

\section{Pengaruh Perlakuan Terhadap Berat}

Telur

Data hasil pengamatan dan perhitungan rata-rata berat telur dari masing-masing perlakuan yang diberikan selama penelitian tercantum pada Tabel 5.Rataan berat telur untuk masing-masing perlakuan berkisar antara 59.516 - 61.606 gr. Hasil penelitian ini masih berada pada kisaran yang dikemukakan oleh (USDA, 2000) menyatakan bahwa rataan berat telur ayam ras termasuk pada kelompok large yaitu 56,7-63,7 gr.

Untuk mengetahui secara jelas bagaimana pengaruh penggunaan tomat pada level $2-8 \%$ terhadap berat telur ayam ras petelur maka dilakukan analisis statistik. Berdasarkan analisis sidik ragam pada lampiran tersebut terlihat bahwa pengaruh penggunaan tomat pada level 2$8 \%$ tidak memberikan pengaruh yang berbeda nyata $(\mathrm{P}>0.05)$ terhadap berat telur ayam ras petelur. Artinya penggunaan $2-8 \%$ tomat dalam ransum belum memberikan perbedaan terhadap berat telur. Tepung tomat kering dapat digunakan sebagai bahan pakan alternatif dalam pemberian pada ayam petelur dengan tingkat inklusi hingga $190 \mathrm{~g} / \mathrm{kg}$ tanpa dampak negatif pada kinerja dan sifat kualitas telur (Mohammad, 2012). 
Tabel 5. Pengaruh Perlakuan Terhadap Berat telur (gr/butir)

\begin{tabular}{|c|c|c|c|c|c|}
\hline \multirow{2}{*}{ Ulangan } & \multicolumn{5}{|c|}{ Perlakuan } \\
\hline & $\mathrm{R}_{0}$ & $\mathrm{R}_{1}$ & $\mathrm{R}_{2}$ & $\mathrm{R}_{3}$ & $\mathrm{R}_{4}$ \\
\hline 1 & 63.44 & 57.72 & 60.98 & 59.68 & 62.55 \\
\hline 2 & 60.83 & 59.79 & 62.00 & 59.74 & 62.52 \\
\hline 3 & 59.41 & 60.95 & 59.31 & 58.51 & 60.50 \\
\hline 4 & 59.93 & 60.97 & 58.86 & 62.98 & 60.02 \\
\hline 5 & 59.93 & 63.28 & 56.43 & 59.16 & 62.44 \\
\hline Total & 303.54 & 302.71 & 297.58 & 300.07 & 308.03 \\
\hline Rataan & 60.708 & 60.542 & 59.516 & 60.014 & 61.606 \\
\hline
\end{tabular}

Pengaruh perlakuan yang tidak berbeda nyata terhadap berat telur pada penelitian ini menggambarkan bahwa penggunaan $2-8 \%$, tidak menyebabkan kenaikan kualitas dan kuantitas telur dalam arti kandungan zat-zat makanan yang digantikan dalam ransum seperti kandungan protein, lemak dan asam-asam amino masih mencukupi kebutuhan ayam ras petelur dan tidak mempengaruhi keseimbangan zat-zat makanan dalam ransum, sehingga pertumbuhan dan produksi telur yang optimum masih dapat tercapai.

Kandungan protein, asam amino dan asam linoleat dalam pakan dapat mempengaruhi bobot telur. Anggrodi (1985) menyatakan bahwa berat telur ditentukan oleh besarnya telur dan berat telur ditentukan oleh faktor genetik, tingkat dewasa kelamin, umur, obat-obatan dan kualitas ransum. Pakan yang mempunyai kualitas baik akan menghasilkan telur yang besar. Oleh karena itu, penurunan bobot telur dapat terjadi karena kandungan asam amino dalam ransum tidak sesuai dengan kebutuhan (Wahju, 1992). Besar kecilnya ukuran telur unggas sangat dipengaruhi oleh kandungan protein dan asam amino essensial dalam pakan ( Latifah, 2007). Yuwono et al (2006) menyebutkan bahwa bobot telur dipengaruhi oleh kualitas bibit (genetik) dan kualitas ransum yang diberikan, disamping faktor-faktor lainnya. North dan Bell (1990) menyatakan, bahwa telur dihasilkan dari induk ayam yang baru bertelur atau induk muda lebih kecil dibandingkan dengan telur yang dihasilkan dari induk yang lebih tua.

\section{Perlakuan Terhadap Berat Kuning}

Telur

Data hasil pengamatan dan perhitungan rata-rata berat kuning telur dari masing-masing perlakuan yang diberikan selama penelitian tercantum pada Tabel 6. Rataan berat kuning telur untuk masing-masing perlakuan berkisar antara 14.696 - 15.664 gr. 
Tabel 6. Pengaruh Perlakuan Terhadap Berat Kuning Telur

\begin{tabular}{|c|c|c|c|c|c|}
\hline \multirow{2}{*}{ Ulangan } & \multicolumn{5}{|c|}{ Perlakuan } \\
\hline & $\mathrm{R}_{0}$ & $\mathrm{R}_{1}$ & $\mathrm{R}_{2}$ & $\mathrm{R}_{3}$ & $\mathrm{R}_{4}$ \\
\hline 1 & 15.33 & 14.06 & 15.21 & 14.58 & 15.38 \\
\hline 2 & 13.62 & 14.66 & 16.06 & 15.24 & 14.56 \\
\hline 3 & 14.98 & 15.55 & 14.83 & 14.47 & 15.59 \\
\hline 4 & 15.07 & 14.76 & 16.17 & 15.31 & 14.52 \\
\hline 5 & 14.86 & 14.45 & 16.05 & 15.48 & 14.42 \\
\hline Total & 73.86 & 73.48 & 78.32 & 75.08 & 74.47 \\
\hline Rataan & 14.772 & 14.696 & 15.664 & 15.016 & 14.894 \\
\hline
\end{tabular}

Hasil penelitian ini masih diatas standar yang dikemukakan Iriyanti et al. (2007) menyatakan bahwa rataan berat kuning telur ayam ras petelur berkisar 9,5$13 \mathrm{~g} / \mathrm{butir}$.

Untuk menyatakan secara jelas bagaimana pengaruh penggunaan tomat pada level 2-8\% terhadap berat kuning telur ayam ras petelur maka dilakukan analisis statistik. Berdasarkan analisis sidik ragam pada lampiran tersebut terlihat bahwa pengaruh penggunaan tomat pada level 2-8\% tidak memberikan pengaruh yang nyata $(\mathrm{P}>0.05)$ terhadap berat kuning telur ayam ras petelur. Artinya penggunaan level 2-8\% tomat dalam ransum belum memberikan perbedaan terhadap berat kuning telur.

Pengaruh perlakuan yang tidak berbeda nyata terhadap berat kuning telur pada penelitian ini menggambarkan bahwa penggunaan level 2-8\% tomat tidak menyebabkan kenaikan kualitas dan kuantitas telur dalam arti kandungan zat- zat makanan yang digantikan dalam ransum terpenuhi.

Leeson dan Summer (1991) menyatakan bahwa berat kuning telur dipengaruhi oleh perkembangan ovarium, berat badan ayam, umur saat mencapai dewasa kelamin, kualitas dan kuantitas pakan, penyakit dan lingkungan dan konsumsi pakan. Proses pembentukkan kuning telur menghasilkan berat kuning telur yang berbeda-beda tergantung dari kemampuan genetis masing-masing individu unggas tersebut (Jeliman, 2009). Persentase kuning telur sekitar 30\%-32\% dari berat telur, komposisi telur adalah air $50 \%$, lemak $32-36 \%$, protein $16 \%$ dan glukosa 1-2\% (Rusadi, 2013).

\section{Pengaruh Perlakuan Terhadap Massa}

\section{Telur}

Data hasil pengamatandan perhitungan rata-rata massa telur dari masing-masing perlakuan yang diberikan selama penelitian tercantum pada Tabel 7 . Rataan massa telur untuk masing-masing 
perlakuan berkisar antara 51,976-55,008 gr/ekor/hari. Hasil penelitian ini masih berada pada kisaran yang dikemukakan oleh (Hy-Line International, 2010) ratarata massa telur pada strain Hy-Line Brown yaitu 50,4-55,3 gr/hari.

Penggunaan tomat pada level 2\%8\% dibandingkan dengan ransum kontrol (ransum basal) terhadap massa telur ayam ras petelur maka dilakukan analisis statistik. Berdasarkan analisis sidik ragam pada lampiran tersebut terlihat bahwa pengaruh penggunaan tomat pada level $2 \%-8 \%$ tidak memberikan pengaruh yang berbeda nyata $(\mathrm{P}>0.05)$ terhadap massa telur ayam ras petelur. Artinya penggunaan $2 \%-8 \%$ tomat dalam ransum belum memberikan perbedaan terhadap massa telur. Pengaruh perlakuan yang tidak berbeda nyata terhadap massa telur pada penelititan ini menggambarkan bahwa penggunaan $2 \%-8 \%$ tomat tidak menyebabkan kenaikan kualitas dan kuantitas telur dalam arti kandungan zatzat makanan yang digantikan dalam ransum masih sama pengaruhnya.

Faktor yang menentukan massa telur adalah jumlah telur dan berat telur. Berat telur ada hubungannya dengan massa telur, dimana pola peningkatan massa telur sejalan dengan pola pertumbuhan folikel dewasa (kuning telur). Berat kuning telur korelasinya positif dengan massa telur dan besar telur, massa telur mencapai puncaknya setelah mencapai umur sekitar 28-34 minggu, cepat lambatnya mencapai puncak serta tinggi rendahnya massa telur ini tergantung pada taraf protein pakan (North dan Bell, 1990).

Tabel 7. Pengaruh Perlakuan Terhadap Massa Telur (g/ekor/hari)

\begin{tabular}{|c|c|c|c|c|c|}
\hline \multirow{2}{*}{ Ulangan } & \multicolumn{5}{|c|}{ Perlakuan } \\
\hline & $\mathrm{R}_{0}$ & $\mathrm{R}_{1}$ & $\mathrm{R}_{2}$ & $\mathrm{R}_{3}$ & $\mathrm{R}_{4}$ \\
\hline 1 & 55,46 & 53,6 & 53,6 & 53,33 & 53,33 \\
\hline 2 & 58,46 & 53,93 & 54,43 & 48,23 & 52,99 \\
\hline 3 & 55,99 & 49,63 & 51,11 & 48,56 & 54,4 \\
\hline 4 & 52,11 & 54,7 & 54,88 & 57,42 & 49,56 \\
\hline 5 & 53,02 & 53,83 & 47,66 & 52,34 & 54,39 \\
\hline Total & 275,04 & 265,69 & 261,68 & 259,88 & 264,67 \\
\hline Rataan & 55,008 & 53,138 & 52,336 & 51,976 & 52,934 \\
\hline
\end{tabular}


Apabila massa telur meningkat maka produksi meningkat pula sebaliknya massa telur turun produksi telur menurun. Lebih lanjut ditambahkan oleh Amrullah (2004) yang menjelaskan bahwa penggunaan massa telur dibandingkan jumlah telur merupakan cara menyatakan perbandingan kemampuan produksi antar kelompok atau galur unggas oleh akibat pemberian makanan dan program pengelolaan yang lebih baik. Berat telur meningkat dari awal sampai akhir produksi tetap massa telur hanya meningkat dari awal produksi sampai dicapai puncak produksi, selanjutnya menurun dengan bertambahnya umur. Peningkatan berat telur diikuti pula dengan menurunnya produksi telur dengan bertambahnya umur setelah dicapai puncak produksi (Scoot et all., 1982).

\section{KESIMPULAN}

Berdasarkan hasil analisis data dan pembahasan untuk semua variabel pada penelitian ini, maka dapat disimpulkan bahwa subtitusi $2 \%-8 \%$ tepung tomat tidak memberikan pengaruh terhadap kualitas berat telur, berat kuning telur dan massa telur.

\section{DAFTAR PUSTAKA}

Abbas MH. 1989 Pengelolaan Produk Unggas. Jilid 1. Universitas Andalas . Padang.

Amrullah, I.K. 2004. Nutrisi Ayam Petelur. Penebar Swadaya. Jakarta.

Anggrodi. R. 1979. Ilmu makanan ternak umum. Cetakan I penerbit PT Gramedia. Yogyakarta.

Anggrodi 1994. Ilmu Makanan Ternak Unggas Cetakan 5. Penerbit PT Gramedia Pustaka Utama, Jakarta.

Franceschi, S., E. Bidoli, C. LaVeccia. R. T alamini, B. D'Avanzo, and E. Negri. 1994. T omatoes and Risk of Digestive-tract Cancers. International Journal of Cancer. 59: 181-184.

Hy-Line International, 2010. Hy-Line International Online Management Guid. http://www.hylineinternational.com Diakses tanggal 25 Maret 2015 k. 08.29.

Iriyanti, N., M. Mufti dan T. Widiyastuti. 2007. Manipulasi Pakan Dengan Imunostimulan Probiotik Dan Prebiotik Terhadap Tampilan Sistem Immunologik Berdasarkan Profil Darah Dan Mikroba Saluran Pencernaan Ayam Petelur, Laporan Penelitian DIPA Program Pascasarjana Fakultas Peternakan, Universitas Jenderal Soedirman, Purwokerto.

Jeliman Y. 2009. Sistem Reproduksi Ayam Betina http://yudig.blogspot.com/systemreproduksiayam-betina.html. Diakses tanggal 25 Maret $2015 \mathrm{pk}$. $\underline{04.54 .}$ 
Kismono SS. 1999. Kualitas Telur. Makalah, Study Program Of Animal Product Technology (APTEC), IPB.

Latifah, R. 2007. The Increasing of Afkir Duck's Egg Quality With Pregnant Mare's Serum Gonadotropin (Pmsg) Hormones. The way to increase of layer duck. 4:1-8

Leeson, S and J. D. Summers. 2001. Comercial Poultry Nutrition. Thirth Edition. Departement of Animal and Poultry Science. University of Guelph Ontariom, Canada.

Mohammad, H.S. 2012. Effects of different levels of dried tomato pomace on performance, egg quality and serum metabolites of laying hens, Department of Animal Science, Faculty of Agricuture, Razi University, Kermanshah, Iran.

North, M.D. 1984. Commercial Chicken Production Manual. 2 ${ }^{\text {nd }}$ Edition. The Avi Publishing Co., connecticub. 358-366; 374-382; $416-489,493 ; 566-578$

North, M. O and D. D. Bell. 1990. Commercial Chicken Production Manual. The AVI Publishing Company, inc. New York.

Rusadi, D. S, 2013. Kualitas Interior Telur Ayam Ras Petelur Berumur Muda. Fakultas Peternakan Universitas Hasanudin. Makasar.
Sudarmono, AS. 2003. Pedoman Pemeliharaan Ayam Ras Petelur. Penerbit Kanisius. Jakarta.

Sudjarwo, E. 2011. Pemanfaatan Tepung Tomat Sebagai Imbuhan Pakan Terhadap Penampilan Reproduksi Itik Mojosari. Universitas Brawijaya Malang.

Scoot, M.L., M.C. Nesheim and R.J. Young. 1982. Nutrition of the Chicken. M.L. Scott and Assiciate. Ithaca. New York.

Tanti, K.D dan Sunarmani. 2008. Parameter likopen dalam standarisasi konsentrat buah tomat. Penelitian pada balai besar penelitian dan pengembangan pascapanen pertanian. Prosiding PPI standarisasi, 25 november 2008

United States Department of Agriculture (USDA). 2000. United States Standards, Grade, and Weight Classes for Shell Eggs. http://www.ams.usda.gov/poultry. Diakses tanggal 25 Maret $\mathrm{pk}$. $\underline{04.33 .}$

Wahju, J. 1992. Ilmu Nutrisi Unggas. Gajah Mada University Press. Yogyakarta.

Yuwono D.M, Subiharta, Hermawan, Hartono. 2006. Produktivitas Itik Tegal di Sentra Pengembangan pada Pemeliharaan Intensif. Balai pengkajian Teknologi Pertanian Jawa Tengah. Unggaran. 